\title{
Defect Identification in Butt Weld Joint by Ultrasonic Method Phased Array and X-Ray Technique
}

Radoslav Konar, Michal Bohacik, Milos Mician

University of Zilina, Faculty of Mechanical Engineering, University of Zilina, Zilina. Slovak Republic. E-mail: radoslav.konar@fstroj.uniza.sk,michal.bohacik@fstroj.uniza.sk,milos.mician@fstroj.uniza.sk

The article deals with the internal defects identification and characterization in butt weld joints by non-destructive ultrasonic Phased Array and X-ray technique. Basics of ultrasonic and X-ray testing are described in the theoretical part of manuscript. Phased Array and X-ray technique are volume nondestructive methods that can detect internal defects without breaking of construction. Ultrasonic Phased array and X-ray test procedures and test results obtained in non-destructive testing of butt weld are shown in experimental part. Ultrasonic record, $X$-ray record and weld macrostructure are given for each identified weld deffect. Advantages and disadvantages as well as comparison of ultrasonic and X-ray testing resulting from experimental measurements are described in the end of this article.

Keywords: Internal weld defects, Butt weld joints, Phased Array, X - ray, Non-destructive testing

\section{Acknowledgment}

This work has been supported by Scientific Grant Agency of Ministry of Education of the Slovak republic, grant KEGA: 034ZU-4/2015.

\section{References}

[1] LANGENBERG, K., J., MARKLEIN, R., MAYER, K. (2012). Ultrasonic nondestructive testing of materials Theoretical foundations. p. 772. CRC Press, New York. ISBN 978-14-398-5588-1

[2] MESKO, J., ZRAK, A., MULCZYK, K., TOFIL, S. (2014). Microstructure analysis of welded joints after laser welding. In: Manufacturing technology: journal for science, research and production, Vol. 14, No. 3, pp. 355359. J.E. Purkyne University, Usti nad Labem. ISSN 1213-2489.

[3] MORAVEC, J., NOVAKOVA, I., BRADAC, J., (2014) Effect of Age Hardening Conditions on Mechanical Properties of AW 6082 Alloy Welds. In: Manufacturing technology: journal for science, research and production, 2016, Vol. 16, No.1, pp. 192-198. J.E. Purkyne University, Usti nad Labem. ISSN 1213-2489.

[4] KONAR, R., MICIAN, M. (2014). Non-destructive testing of welds in gas pipelines repairs with Phased Array ultrasonic technique. In: Manufacturing technology: journal for science, research and production, Vol. 14, No. 1, pp. 42-47. J.E. Purkyne University, Ústi nad Labem. ISSN 1213-2489.

[5] RADEK, N., MEŠKO, J., ZRAK, A. (2014). Technology of laser forming. In: Manufacturing technology: journal for science, research and production, Vol. 14, No. 3, pp. 428-431. J.E. Purkyne University, Usti nad Labem. ISSN 1213-2489.

[6] LAGO, J. et al. (2016) Influence of Laser Shock Peening Surface Treatment on Fatigue Endurance of Welded Joints from S355 Structural Steel. In: Manufacturing technology: journal for science, research and production, 2016, Vol. 16, No.1, pp. 154-159. J.E. Purkyne University, Usti nad Labem. ISSN 1213-2489.

[7] OLYMPUS (2013). The company Olympus NDT. Online: <http://www.olympus-ims.com/cs>.

[8] KOPEC, B. et al.: Nondestructive Testing of Materials and Structures, p. 573, CERM, s.r.o.: Brno, 2008, ISBN 978-80-7204-591-4.

[9] BOHACIK, M. (2016). Comparison of the reliability of the identifications of internal defects butt welded joints by ultrasonic and x-ray checking: Diploma work. Zilina: University of Zilina in Zilina, 2016. 67s.

[10] BRUNA, M., KUCHARCIK, L., SLADEK, A. (2013). Complex evaluation of porosity in A356 aluminium alloy using advanced porosity module. In: Manufacturing Technology: journal for science, research and production, Vol. 13, No. 1, pp. 26-30. J.E. Purkyne University, Usti nad Labem. ISSN 1213-2489.

[11] MEŠKO, J. - ZRAK, A. - MULCZYK, K. - TOFIL, S.: Microstructure analysis of welded joints after laser welding, In: Manufacturing Technology: journal for science, research and production, Vol. 14, No. 3, pp. 355-359. J.E. Purkyne University, Usti nad Labem. ISSN 1213-2489. 